\title{
Global and regional estimates of the morbidity due to type I diabetes among children aged 0-4 years: a systematic review and analysis
}

\author{
Davies Adeloye ${ }^{1}$, Kit Yee Chan ${ }^{1}$, \\ Natasha Thorley ${ }^{1}$, Charlotte \\ Jones $^{1}$, David Johnstone ${ }^{1}$, \\ Ari L'Heveder' ${ }^{1}$, Vanja Saftic ${ }^{2,3}$, \\ David Henderson ${ }^{1}$, Mickey \\ Chopra $^{4}$, Harry Campbell ${ }^{1}$, \\ Igor Rudan ${ }^{1}$

\footnotetext{
${ }^{1}$ Centre for Global Health Research and World Health Organization's Collaborating Centre for Population Health, Research and Training, The Usher Institute, University of Edinburgh, UK

${ }^{2}$ Child and Youth Protection Center of Zagreb, Croatia

${ }^{3}$ Croatian Catholic University, Zagreb, Croatia

${ }^{4}$ The World Bank Group, Washington, D.C., USA
}

\begin{abstract}
Background Epidemiology of type 1 diabetes mellitus (T1DM) among children aged 0-4 years globally is not well understood. We aim to assess the incidence of T1DM in low- and middle-income countries (LMIC) by conducting a systematic review of previous reports. We also aim to address possible contribution to child mortality and to identify any temporal trends.
\end{abstract}

Methods A systematic review was performed using a carefully designed search strategy to explore MEDLINE, EMBASE and Global Health databases. Data was extracted from all studies that satisfied the inclusion criteria - a total of 83 records extracted from 26830 sources that were analysed. We used the Grading of Recommendations Assessment, Development and Evaluation (GRADE) process to assess quality of evidence and applied meta-analysis approaches to assess global and regional incidence and time trends.

Results The overall pooled incidence of T1DM in children aged 0-4 years globally is $11.2(95 \% \mathrm{CI}=10.0-12.3)$ per 100000 child years. The regional incidence were the highest for European Region A (EUR A) at 15.5 (95\% CI $=13.5-17.5)$ per 100000 child years. EUR C had the incidence of 10.0 (95\% CI=6.5-13.6) and EUR B 5.8 (95\% CI=4.7-7.0), Region of the Americas A (AMR A) 11.4 (95\% CI=7.8-14.9), AMR B of 2.5 (95\% CI=0.2-4.8), Eastern Mediterranean Region (EMR B) 7.1 (95\% CI =4.2-10.0) and Western Pacific Region (WPR A) 7.0 (95\% $\mathrm{CI}=2.9-11.0)$ per 100000 child years, while other regions had very low rates or no data. When data points were categorised in the study periods and re-analysed, an increasing trend of the T1DM incidence was observed, with the incidence of 20.9 (95\% CI=7.8-34.1) per 100000 child years in the years 2010-2015, preceded by $13.2(95 \%$ $\mathrm{CI}=11.0-15.5)$ in 2000-2009 study period, 10.0 (95\% CI=8.4-11.7) in 1990-1999 and 8.3 (95\% CI=5.1-11.6) in 1980-1989, respectively. Although the data are scarce, and variation and uncertainty are large, we estimated that the number of new cases of T1DM among children aged 0-4 years in the world each year is between 100000 and 150000 .

Conclusions The identified large variation in incidence estimates for different parts of the world, along with scarcity of information and the identified strong temporal increase in T1DM incidence suggest a clear need for further research into this subject.

The epidemiology of type 1 diabetes mellitus (T1DM) is increasingly studied across several world regions to provide better understanding of the disease in these settings and prompt relevant public health and policy response $[1,2]$. According to the International Diabetes Federation (IDF) 
atlas, about 151 million people were estimated to have any type of diabetes globally in 2000 [3], 194 million in 2003 [4], 246 million in 2006 [5], 415 million in 2015 and a projected increase to 642 million by 2040 [6,7]. Mortality from diabetes globally increased from 16.3/100 000 to 19.5/100000, and disability adjusted life years (DALYs) also increased from 523/100 000 to 680/100 000 between 1990 and 2015 respectively $[8,9]$.

T1DM remains a large public health concern globally, especially due to fast rising and varying incidence reported across diverse population groups [10]. According to the WHO Multinational Project for Childhood Diabetes (DiaMond) Research Group, overall age-adjusted incidence of T1DM varied from 0.1 in China and Venezuela to 37 per 100000 person-years in Sardinia and in Finland, accounting for over 350fold difference in the TIDM incidence in about a hundred different populations of children aged 0-14 years studied worldwide in early 1990s [11]. Experts have reported that this marked variation may reflect the heterogeneity within and between major ethnic populations globally $[12,13]$, which possibly account for the hereditary and genetic factors indicated in the aetiology of T1DM. For example, T1DM incidence was reported to be higher among populations of white European ancestry, as observed in Nordic populations of Finland, Sweden, and Norway compared to other world regions [11]. In Israel, marked ethnic variations were observed, especially between Jewish and Arab populations [11]. In Africa, geographical and ethnic variations were observed in some populations in Tanzania, Nigeria, South Africa, and Ethiopia [14-16]. Although, genetic factors have been indicated in the development of T1DM, it is important to note that the aetiology is actually multifactorial, for which several theories have been suggested [17].

Meanwhile, increasing incidence and mortality from T1DM has been reported in children and adolescents, especially in Central America, West Indies and several European countries [13]. A statistically significant increase in T1DM incidence of $65 \%$ was noted in all the population that were studied, mostly in the younger age groups [18]. In Europe, annual increment in incidence of T1DM in children ranged from 0.6\%-15\% across the 36 EURODIAB centres in the period 1989-2003 [10]. Moreover, in the US multicentre Search for Diabetes in Youth Study (SEARCH), there was marked annual increase in the incidence of TIDM in non-Hispanic White younger than 14 years, with a mean of 27.5 per 100000 per year [19].

Patterson and colleagues provided worldwide estimates of T1DM in children aged 0-14 years, and highlighted challenges in the collation of epidemiological reports on T1DM in this age group [12]. There are currently few reports on deaths from TIDM, especially from Africa and many low- and middle-income countries (LMICs) [20]. Major causes of deaths have been linked to poor diagnosis and treatment, with many presenting with acute complications, infections, cardiovascular diseases and chronic kidney diseases [2], with many calling for improved and continuous strategies for disease prevention, diagnosis and treatment on a population-wide scale [21]. In fact, speculations were reported hypothesising that T1DM could perhaps explain a major part of the unclassified causes of 0-14 years mortality in many low-resource settings [22]. In the light of the relatively poor understanding of the burden of T1DM in LMICs, especially among children under five years, this study aimed to review available evidence on T1DM in children aged 0-4 years globally in order to contribute to the understanding of the epidemiology, and provide improved estimate of the incidence of the disease in this age group.

\section{METHODS}

\section{Search strategy}

After identification of relevant Medical Subject Headings (MESH) and keywords, a final search strategy was developed. Searches were conducted on three main databases: Medline, EMBASE and Global Health. Literature searches were conducted on 15 August 2018. The search date was set from January 1980 to date (Tables S1-S3 in Online Supplementary Document).

\section{Selection criteria}

We included i) studies published from 1980 to 2017 globally that referred to diabetes among children, ii) studies that directly attempted to estimate the prevalence, incidence and/or under-five mortality from T1DM across various world regions, and iii) studies that provided information that helps to understand the determinants of the occurrence and aetiology, clinical features, management, case-fatality rates, and outcomes of T1DM in children.

We excluded i) studies that are reviews, viewpoints and commentaries, iii) studies that do not report relevant denominators from which prevalence, incidence and/or under-five mortality from T1DM can be 
estimated, iv) studies with ambiguous study designs and analysis, v) studies without active follow-up periods, and vi) studies with case definitions not clearly defined and consistently applied.

\section{Case definitions}

In this review, we included studies that clearly reported TIDM diagnosis (based on registries and a clinical diagnosis of type 1 diabetes). Case definitions employed across studies varied, including the WHO criteria [23,24], the American Diabetic Association (ADA) criteria [25,26], and the WHO-IDF recommendation diagnosis of diabetes [27]. The final case definitions employed in the selection criteria were as follows:

i. Fasting plasma glucose level at or above $7.0 \mathrm{mmol} / \mathrm{L}(126 \mathrm{mg} / \mathrm{dL})$;

iii. Symptoms of hyperglycemia and casual plasma glucose at or above $11.1 \mathrm{mmol} / \mathrm{L}$ (200 mg/dL).

iii) Glycated hemoglobin (hemoglobin AlC) at or above $48 \mathrm{mmol} / \mathrm{mol}$ ( $\geq 6.5$ Diabetes Control and Complications Trial DCCT \% [28] (Table 1).

\section{Quality criteria and grading}

Quality of individual studies was assessed based on the following criteria:

i. Study design: Under this, flaws in the design and execution of study were examined. Basically, this assesses methods of estimation of sample size and sampling methods across studies (if necessary), and the methods of dealing with design specific issues such as: training of study investigators, adherence to standardized protocol and case definitions/ascertainment for determining T1DM

ii. Study analysis: This assesses the appropriateness of statistical and analytical methods employed across studies;

iii. Study limitations: This assesses if the study explicitly stated the limitations, as this may further guide in the choice of selection; and

iv. Generalizability to a larger population: This broadly assesses if the sample size or study population was representative of a larger population in the region of study.

For the quality grading, the Grading of Recommendations Assessment, Development and Evaluation (GRADE) guidelines [29] were adapted:

i. High-quality: Studies with all four criteria, or any three including "study design" highlighted above, well represented;

ii. Moderate-quality: Studies with any three of the four criteria, or any two including "study design" highlighted above, well represented;

iii. Low-quality: Studies with any two of the four criteria or "study design" only, highlighted above, well represented; and

iv. Very low-quality: Studies with only one (excluding "study design") or none of the four criteria highlighted above, well represented.

As a basic rule, all studies that were graded as high and moderate quality were included in the quantitative analysis. Some low-quality studies were also included in the quantitative analysis on the basis of good study designs, and details of these studies will be described further in the discussion section. However, all very low-quality studies have been excluded.

Table 1. Diagnostic criteria for diabetes*

\begin{tabular}{|c|c|c|c|c|}
\hline Condition (Unit) & $\begin{array}{l}\text { Casual glucose } \\
\text { MMOLLL(MG/DL) }\end{array}$ & Fasting gLucose MMoL/L(me/DL) & $\mathrm{HBA}_{1 \mathrm{c}}$ (MMOL/MoL) & DCCT $\%$ \\
\hline Normal & $<7.8(<140)$ & $<6.1(<110)$ & $<42$ & $<6.0$ \\
\hline Impaired fasting glycaemia & $<7.8(<140)$ & $\geq 6.1(\geq 110) \&<7.0(<126)$ & $42-46$ & $6.0-6.4$ \\
\hline Impaired glucose tolerance & $\geq 7.8(\geq 140)$ & $<7.0(<126)$ & $42-46$ & $6.0-6.4$ \\
\hline Diabetes mellitus & $\geq 11.1(\geq 200)$ & $\geq 7.0(\geq 126)$ & $\geq 48$ & $\geq 6.5$ \\
\hline
\end{tabular}

$\mathrm{mmol} / \mathrm{l}(\mathrm{mg} / \mathrm{dl}$ ) - millimoles per litre (milligrams per decilitre), HbAl - Hemoglobin Alc, DCCT - Diabetes Control and Complications Trial.

*Source: [24-28]. 


\section{Data extraction}

To allow for consistency, parallel searches were conducted following a predesigned guideline. Disagreements in study selections were resolved by consensus. Data were abstracted systematically on period of study, location, study population, mean age or age range, number of T1DM cases, incidence, prevalence (if reported), and number of deaths from TIDM (if reported). All data were categorised by the World Health Organization (WHO) regions and study periods for further analysis. For studies conducted on the same study site, population or cohort, the first chronologically published study was selected, and all additional data from other studies were included in the selected paper.

\section{Data analysis}

A random-effects meta-analysis (DerSimonian and Laird method) was conducted on extracted crude incidence rates [30]. This was reported separately for the WHO regions and study periods, all expressed per 100000 child years (population data were as reported in studies). Standard errors were determined from the reported crude estimates and child-years of follow-up, assuming a binominal (or Poisson) distribution. Heterogeneity between studies was assessed using I-squared $\left(\mathrm{I}^{2}\right)$ statistics, and subgroup analysis was conducted to detect causes of heterogeneity. Weights were based on reported study population size, and data from multiple study sites were combined. However, estimates from countries with data available were only extrapolated to for the WHO region of those countries, and not individually for other countries in the same region. There were no data points on deaths in under-fives, most T1DM paediatric studies that reported deaths were in the age 0-14 years and did not provide breakdowns to allow extraction of deaths in under-fives. Based on published statistical evidence on chronic diseases, we assumed the prevalence of T1DM at any point in time to be about five times greater than the incidence [31]. In addition, based on the assumption of stable demographic changes in children aged 0-4 years globally, number of TIDM incident cases was extrapolated from the meta-estimates for the years 1990, 2010, and 2015 using the United Nations (UN) population projections [32]. All statistical analyses were conducted on STATA

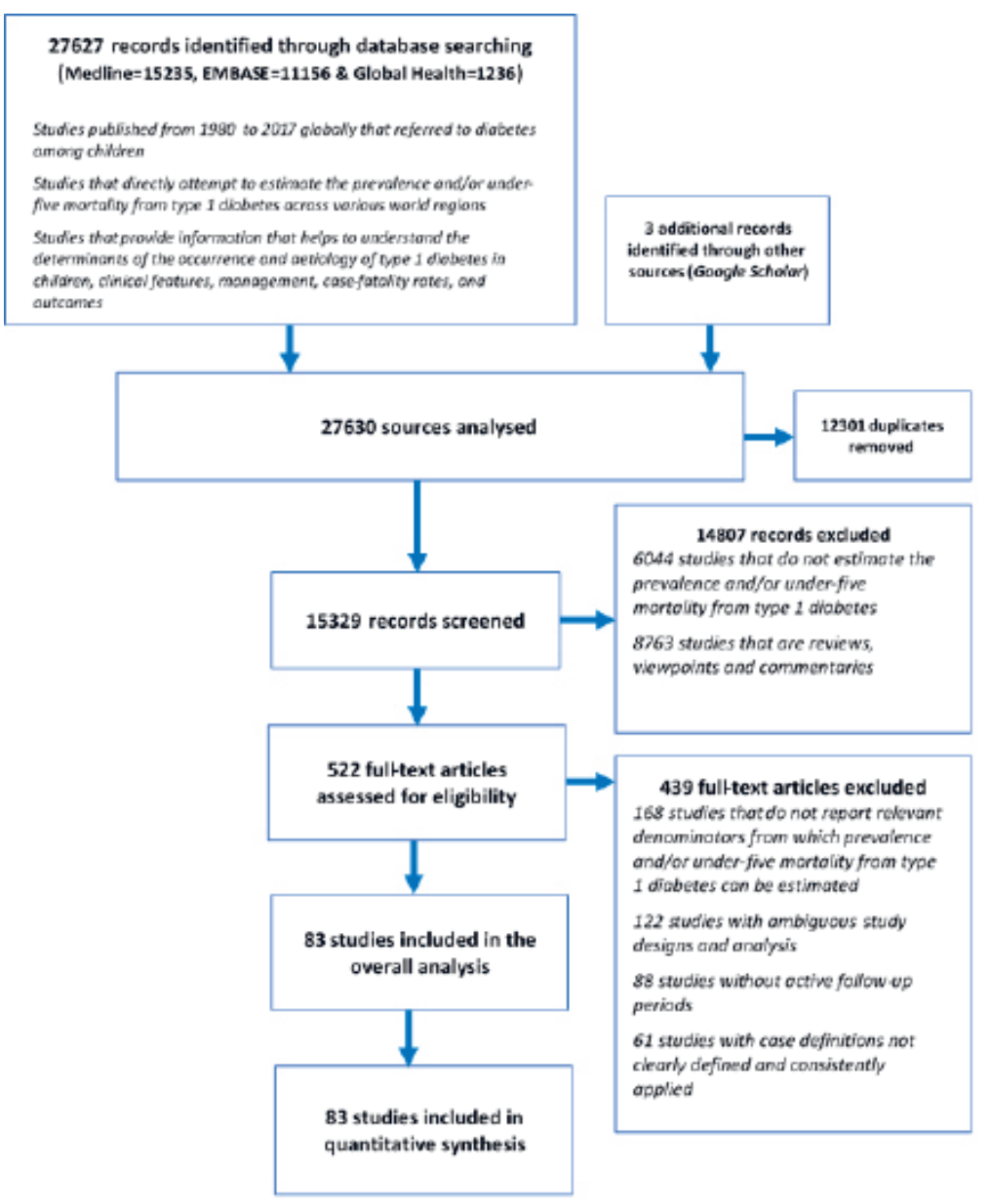

Figure 1. Flowchart of study selection.
(Stata Corp V.15, College Station, Texas TX, USA). This study was conducted in line with the Preferred reporting items for systematic reviews and meta-analyses (PRISMA) statement.

\section{RESULTS}

\section{Literature search}

A total of 27627 records were identified through database searching (Medline 15235, EMBASE 11156 and Global Health 1236) and 3 additional records were obtained from Google Scholar, resulting in a total of 27630 records analysed. After removing duplicates, 15329 records remained. Of these, 14807 records were excluded, giving a total of 522 fulltext articles assessed for eligibility. Then, 439 full-text articles were further excluded. A total of 83 studies were finally included for the analysis [10,11,13,17,19-23,33-106] (Figure 1, and Table S4 in Online Supplementary Document).

\section{Study characteristics}

The numbers of studies conducted in declining order by decade were: 1990-1999 (36 studies), 2000-2009 (28 studies), 1980-1989 (14 studies), and 2010-2017 (5 studies). Most of the studies - 56 in total - were conduct- 


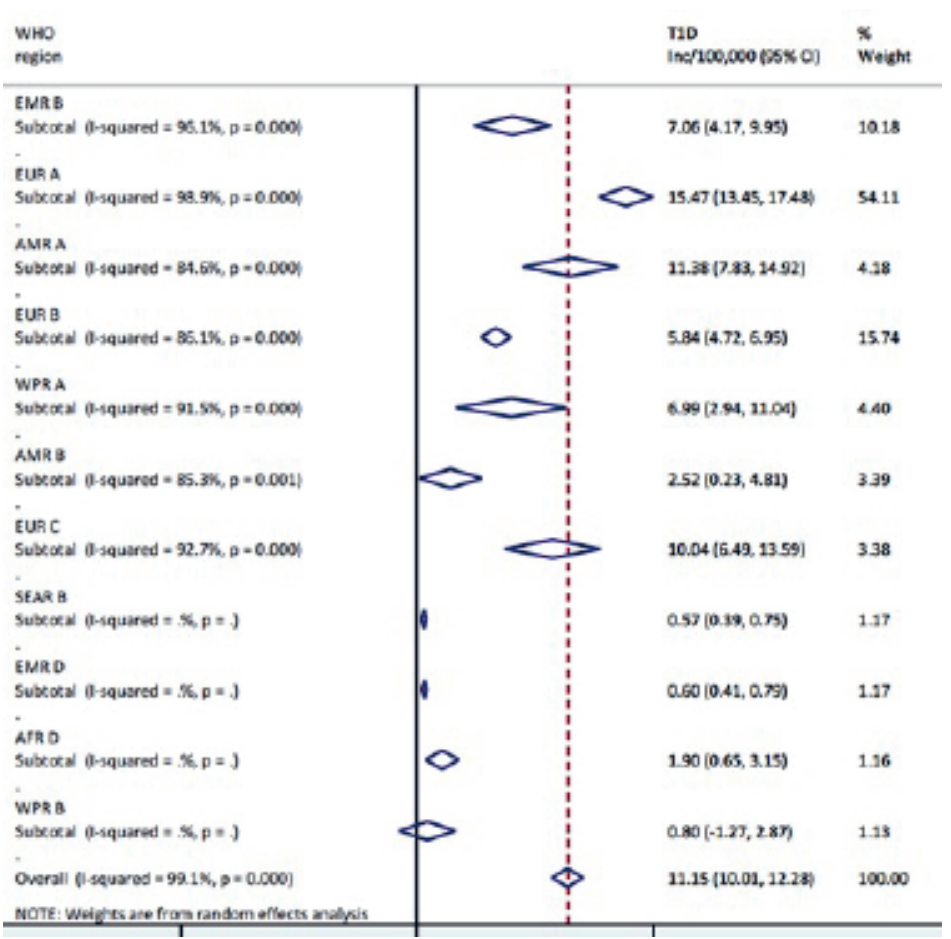

Figure 2. Meta-estimate of the incidence rate of type 1 diabetes mellitus by WHO regions. ed in the European region (EUR A-39, EUR B-14, EUR C-3). Eastern Mediterranean Region (EMR) contributed 11 studies, American region (AMR) 8 studies, Western Pacific region 6 studies, while South East Asian (SEAR) and African regions (AFR) had only 1 study each. About two-thirds of selected studies were rated as high-quality with most of these $(70.5 \%)$ conducted in the European region. See Appendix S1 in Online Supplementary Document for the full list of studies and study characteristics.

\section{Incidence rates of T1DM}

The overall pooled incidence of T1DM in children aged 0-4 years globally is 11.2 (95\% CI $=10.0$ 12.3) per 100000 child years. Heterogeneity was high across studies, with $\mathrm{I}^{2}$ estimated at $99.1 \%, P<$ 0.000. The regional estimates showed that European region had the highest pooled incidence, with EUR A leading all regions at 15.5 (95\% CI = 13.517.5) per 100000 child years. However, EUR C had 10.0 (95\% CI =6.5-13.6) per 100000 child years, and EUR B 5.8 (95\% CI=4.7-7.0) per 100000 child years, ie, considerably lower rates. The American region also showed variation, with AMR A incidence of 11.4 (95\% CI=7.8-14.9) and AMR B of

2.5 (95\% CI =0.2-4.8) per 100000 child years, respectively. High incidence rates were recorded in EMR B with 7.1 (95\% CI=4.2-10.0) and WPR A with 7.0 (95\% CI=2.9-11.0) per 100000 child years, respectively (Figure 2 and Figure 3).

When data points were categorised according to the study periods and re-analysed, an increasing trend of the T1DM incidence was observed (Figure 4 and Figure 5). The highest pooled incidence of T1DM was recorded in the years 2010-2015, with $20.9(95 \% \mathrm{CI}=7.8-34.1)$ per 100000 child years. This was preceded by the 2000-2009 study period, with an incidence rate of 13.2 (95\% CI=11.0-15.5) per 100000 child years. The years 1990-1999 and 1980-1989 showed pooled incidence of 10.0 (95\% CI=8.4-11.7) and 8.3 (95\% CI=5.1-11.6) per 100000 child years, respectively. Using the United Nations population projection, and assuming demographic factors and differences between world regions were fully accounted for, these rates would amount to about 53000 new cases in children aged 0-4 years in 1990, 62000 new cases in 2000, 84000 new cases in 2010, and 136000 new T1DM cases in 2015, respectively. Given that very few deaths are identified in this age group (although the data on mortality in 0-4 year group are remarkably scarce), the prevalence at any point in time should be expected to be about 5 times greater than the incidence,

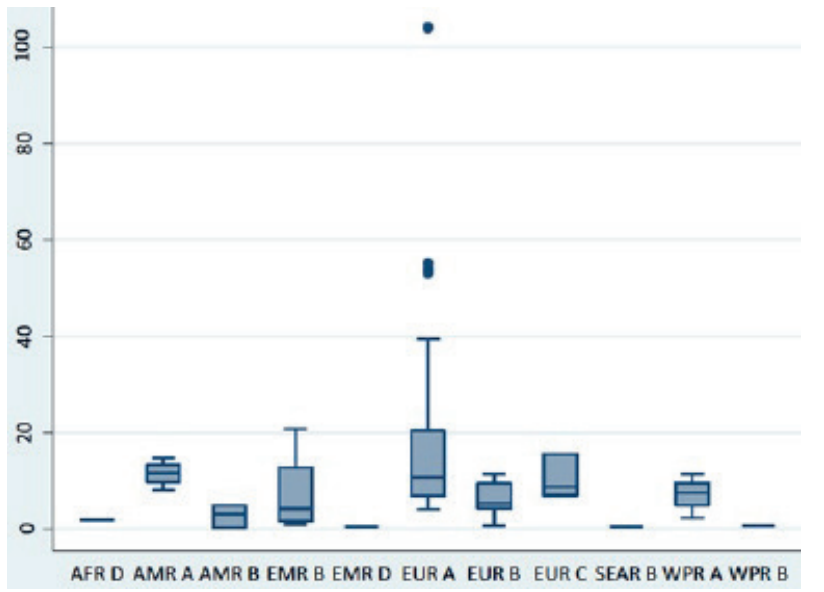

Figure 3. Box and whisker plot of the incidence rate of type 1 diabetes mellitus by WHO regions. ie, to range from about 300000 cases in 1990 to just under 700000 in 2015. Still, there is a very considerable uncertainty about these estimates, with hardly any understanding of case-fatality rate in this period.

In order to speculate about the mortality from T1DM in the age group 0-4 years, we could apply historic mortality rates from the 19th century and early 20th century from USA and Scandinavian countries, which were in range of 1-4 per 100000 per child years - (these rates were relevant to the age group of $0-14$ years).

If those rates were applied to the global child population aged 0-4 years today, they would result in 6500 to 26000 child deaths. However, given the near-certain fact that those deaths were predominantly occurring after year 4 , and that there are treatment options currently available, it would be surprising 


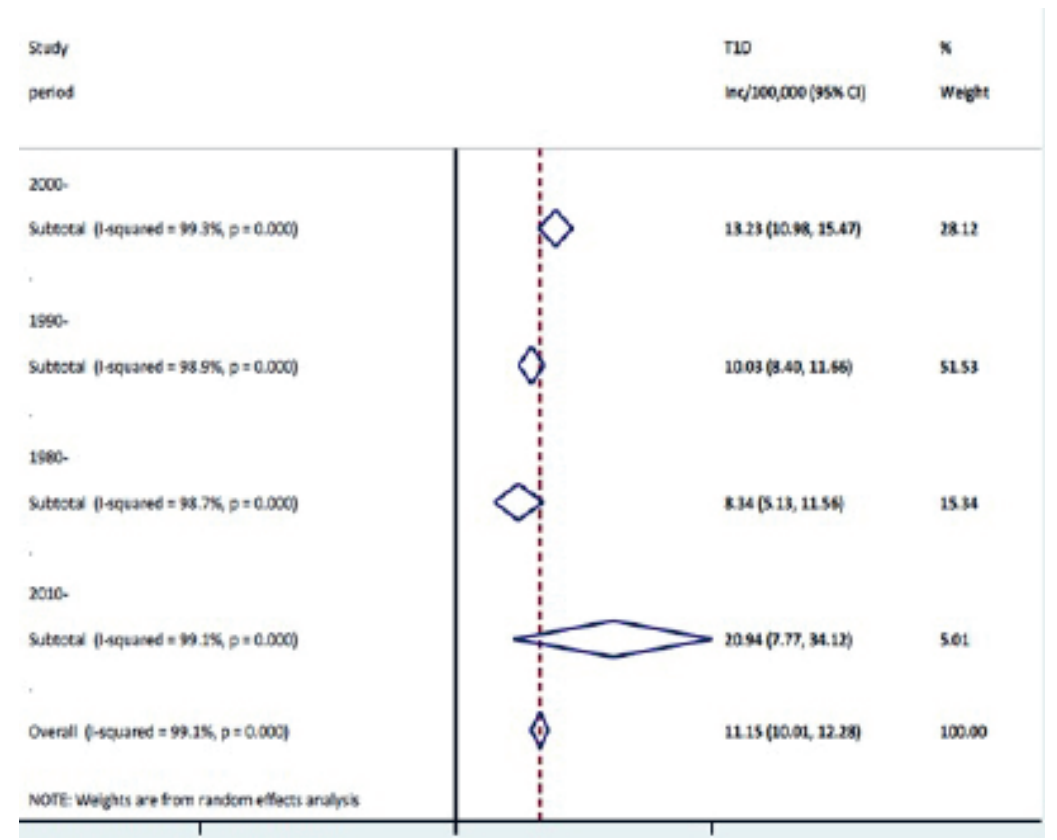

Figure 4. Meta-estimate of the incidence rate of type 1 diabetes mellitus by study period.

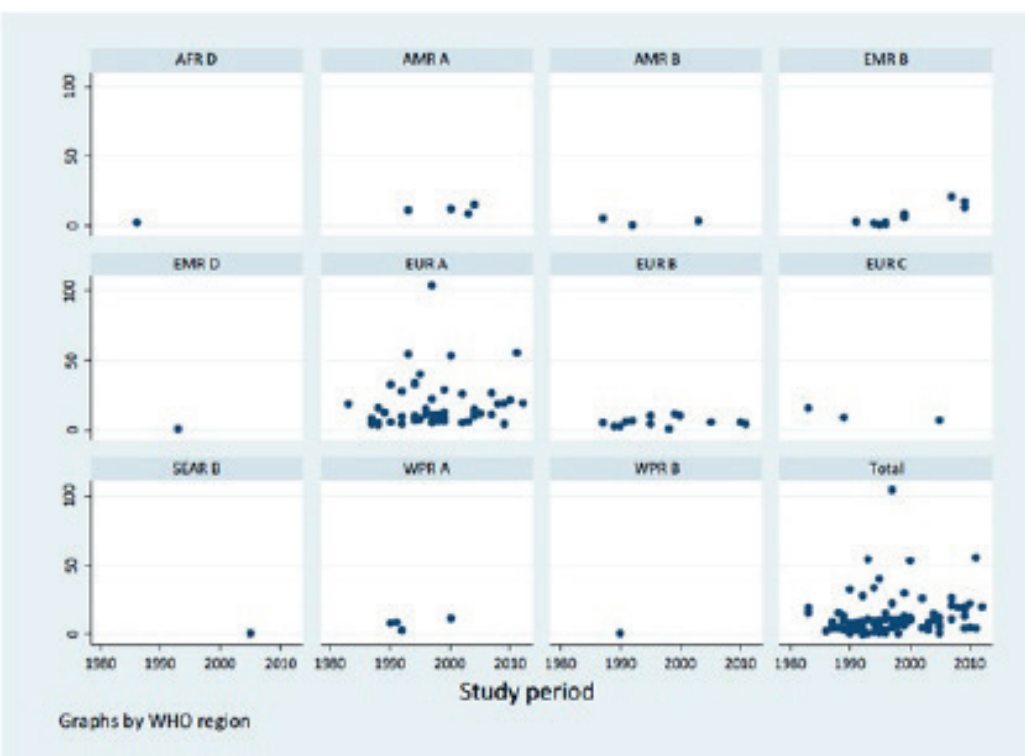

Figure 5. Incidence rate of type 1 diabetes mellitus by study period. if the number of deaths in this period globally amounted to a four-digit number, rather it would likely be measured in hundreds.

\section{DISCUSSION}

This study, to the best of our knowledge, provides the first systematically derived global and regional estimate of the incidence of type 1 diabetes among children aged 0-4 years. Prior to the conduct of this study, there have been some efforts to describe the burden of TIDM in children globally, notably the WHO DiaMond project, which used standardized type 1 diabetes incidence registries worldwide [11]. Despite using a capture-recapture method to ascertain completeness of registry, one major limitation of this study was relative under-reporting and under-estimation of most registries, especially in developing countries, where secondary sources of case ascertainment are largely unavailable. Indeed, few studies on the epidemiology of T1DM exists globally, most of these focus on clinical diagnosis and treatment, and are generally on adolescent populations [107]. In view of current reports suggesting an increased prevalence or incidence in younger population groups [108], an understanding of the number of cases in children, especially under-fives, which this current study is providing, may be worthwhile.

In this study, the overall pooled incidence of T1DM in children aged 0-4 years globally in 2015 was 20.9 (7.8-34.1) per 100000 child years, accounting for about $136000 \mathrm{TlDM}$ cases. Our findings are higher than previously reported, and may further support recent reports that increasing incidence of T1DM is shifting towards younger age groups [108]. In the DiaMond study, a total of 19164 T1DM cases in children aged 0-14 years were identified in over 100 centres with age-adjusted incidence ranging from 0.1-36.8 per $100000 / y[11]$.

A consistently increasing incident cases of T1DM was further observed over the study period, with about $53000,62000,84000$, and 136000 T1DM cases estimated in children aged 0-4 years in 1990, 2000, 2010 and 2015, respectively. This finding, although significantly higher than previous estimates, is supported by many studies. In the WHO DiaMond study, between 1990 and 1994, the average increase in the incidence of T1DM was 2.4\%, with this increasing to 3.4\% the during the years 1995-1999. Patterson and colleagues predicted the global prevalence of T1DM will increase from 94000 in 2005 to 160000 in 2020, with this likely doubling in children younger than five years [10]. Onkamo et al. also reported that the incidence of T1DM is increasing in low and high incidence populations, and that by the year 2010, the incidence in many other populations may be over 30 per 100000/y [18].

Meanwhile, we observed our 2010 and 2015 estimates are higher than annual type 1 diabetes cases of 77880 and 96100 in children 0-14 years reported by IDF in 2011 and 2017, respectively [109]. We be- 
lieve, this contrast, is due to our subgroup-analysis by study period, which clearly showed an increasing trend. Several authors have suggested that the global increase over the years in the incidence of T1DM may be due to better case ascertainment and registration process across many developing countries [2,13]. However, without a subgroup-analysis, our overall pooled estimate from all studies at 11.2 per 100000 would account for about 73000 cases of T1DM in children under 5 years in 2015, which may not be too far from the IDF estimates.

From the regional estimates, the European region had the highest TIDM incidence rate with EUR A leading all regions at 15.5 (13.5-17.5) per 100000 child years, and this is followed by the American region, with AMR A having 11.4 (7.8-14.9). According to the WHO DiaMond study, higher incidence rates of TIDM have been observed Europe and North America, mostly due to the fact that most registries in these regions have been established as far back as the 1980s, and are therefore better equipped to collate relatively complete data on T1DM than other world regions [110]. As noted in the introduction, geographical and climatic factors may have also influenced distribution of mean incidence rates of T1DM globally [111,112]. Emerging evidence also suggests that environmental factors are now able to initiate the development of T1DM in genotypes previously not known to be associated with the disease [2]. However, some experts have stated that geographical and environmental influences do not overtly account for the rapidly increasing incidence of T1DM $[113,114]$.

As observed in this study, some studies have also noted that data from African and South East Asia are still relatively sparse, thus making the understanding of T1DM in the regions quite difficult $[11,107]$. These are therefore regions requiring further epidemiological surveys and research to contribute to better understanding of T1DM globally.

This study could have been limited by a number of factors. However, one major constraint, which has already been reported in previous studies, is that most of the publications in this review were from the European region. This implies that estimates may reflect more the conditions in these settings, and may not be generalizable to other world regions. Moreover, with Africa having only one study, it may be important to raise more awareness in this region on TIDM among children aged 0-4 years, especially to support efforts (including availability of insulin) targeted at regions with very low national income, large child populations and poor child health outcomes. Additionally, there were no studies that reported mortality and case fatality rates from TIDM in children aged 0-4 years, as this would have contributed significantly to the understanding of its epidemiology and instituting necessary intervention measures. Largely, type 1 diabetes seems to be another major gap in global child health estimates. While the prevalence and incidence patterns across many child populations appear to be unfolding, it still remains unclear if this would contribute to increase child mortality, especially in the 0-4 years age group. It is however certainly worth addressing in terms of morbidity and mortality in LMICs, as new information is beginning to emerge.

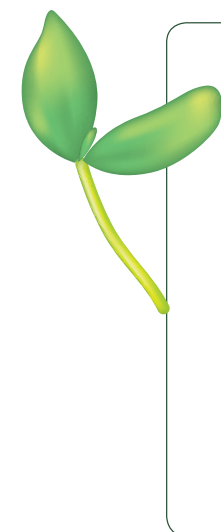

Funding: This study was supported by the Maternal and Child Epidemiology Estimates (MCEE) grant from the Bill and Melinda Gates Foundation and by The World Bank Group.

Authorship declaration: IR, HC, DA and KYC conceptualized and designed the study. NT, CJ, DJ, ALH, VSS and DH conducted the literature searches and prepared the data. DA, KYC and IR conducted the analysis. DA, KYC, MC, HC and IR wrote the manuscript. All authors have critically reviewed and approved the final manuscript as submitted.

Competing interest: Igor Rudan and Harry Campbell are the Co-Editors in Chief of the Journal of Global Health. To ensure that any possible conflict of interest relevant to the journal has been addressed, this article was reviewed according to best practice guidelines of international editorial organizations. The authors completed the Unified Competing Interest form at www.icmje.org/coi_disclosure.pdf (available on request from the corresponding author). The authors declare no competing interests. 
1 Borchers AT, Uibo R, Gershwin ME. The geoepidemiology of type 1 diabetes. Autoimmun Rev. 2010;9:A355-65. Medline:19969107 doi:10.1016/j.autrev.2009.12.003

2 Assayed A. Diabetes in Africa: the dark tunnel. Afr Health. 2013;35:34-6.

3 International Diabetes Federation. Diabetes Atlas, 1st ed. Brussels: International Diabetes Federation; 2000.

4 International Diabetes Federation. Diabetes Atlas, 2nd ed. Brussels: International Diabetes Federation; 2003.

5 International Diabetes Federation. Diabetes Atlas, 3rd ed. Brussels: International Diabetes Federation; 2006.

6 Whiting DR, Guariguata L, Weil C, Shaw J. IDF diabetes atlas: global estimates of the prevalence of diabetes for 2011 and 2030. Diabetes Res Clin Pract. 2011;94:311-21. Medline:22079683 doi:10.1016/j.diabres.2011.10.029

7 Ogurtsova K, da Rocha Fernandes JD, Huang Y, Linnenkamp U, Guariguata L, Cho NH, et al. IDF Diabetes Atlas: Global estimates for the prevalence of diabetes for 2015 and 2040. Diabetes Res Clin Pract. 2017;128:40-50. Medline:28437734 doi:10.1016/j.diabres.2017.03.024

8 GBD 2016 Disease and Injury Incidence and Prevalence Collaborators. Global, regional, and national incidence, prevalence, and years lived with disability for 328 diseases and injuries for 195 countries, 1990-2016: a systematic analysis for the Global Burden of Disease Study 2016. Lancet. 2017;390:1211-59. Medline:28919117 doi:10.1016/S01406736(17)32154-2

9 Murray CJ, Vos T, Lozano R, Naghavi M, Flaxman AD, Michaud C, et al. Disability-adjusted life years (DALYs) for 291 diseases and injuries in 21 regions, 1990-2010: a systematic analysis for the Global Burden of Disease Study 2010. Lancet. 2012;380:2197-223. Medline:23245608 doi:10.1016/S0140-6736(12)61689-4

10 Patterson CC, Dahlquist GG, Gyurus E, Green A, Soltesz G, Group ES. Incidence trends for childhood type 1 diabetes in Europe during 1989-2003 and predicted new cases 2005-20: a multicentre prospective registration study. Lancet. 2009;373:2027-33. Medline:19481249 doi:10.1016/S0140-6736(09)60568-7

11 Karvonen M, Viik-Kajander M, Moltchanova E, Libman I, LaPorte R, Tuomilehto J. Incidence of childhood type 1 diabetes worldwide. Diabetes Mondiale (DiaMond) Project Group. Diabetes Care. 2000;23:1516-26. Medline:11023146 doi:10.2337/diacare.23.10.1516

12 Patterson C, Guariguata L, Dahlquist G, Soltesz G, Ogie G, Silink M. Diabetes in young —a global view and worldwide estimates of numbers of children with type 1 diabetes. Diabetes Res Clin Pract. 2014;103:161-75. Medline:24331235 doi:10.1016/j.diabres.2013.11.005

13 Patterson CC, Gyurus E, Rosenbauer J, Cinek O, Neu A, Schober E, et al. Trends in childhood type 1 diabetes incidence in Europe during 1989-2008: evidence of non-uniformity over time in rates of increase. Diabetologia. 2012;55:2142-7. Medline:22638547 doi:10.1007/s00125-012-2571-8

14 McLarty DG, Athaide I, Bottazzo GF, Swai AM, Alberti KG. Islet cell antibodies are not specifically associated with insulin-dependent diabetes in Tanzanian Africans. Diabetes Res Clin Pract. 1990;9:219-24. Medline:2226121 doi:10.1016/01688227(90)90048-X

15 Lutale JJ, Thordarson H, Holm PI, Eide GE, Vetvik K. Islet cell autoantibodies in African patients with Type 1 and Type 2 diabetes in Dar es Salaam Tanzania: a cross sectional study. J Autoimmune Dis. 2007;4:4. Medline:17963519 doi:10.1186/1740-2557-4-4

16 Panz VR, Kalk WJ, Zouvanis M, Joffe BI. Distribution of autoantibodies to glutamic acid decarboxylase across the spectrum of diabetes mellitus seen in South Africa. Diabet Med. 2000;17:524-7. Medline:10972582 doi:10.1046/j.1464$5491.2000 .00324 . x$

17 Froehlich-Reiterer EE, Rosenbauer J, Bechtold-Dalla Pozza S, Hofer SE, Schober E, Holl RW, et al. Predictors of increasing BMI during the course of diabetes in children and adolescents with type 1 diabetes: data from the German/Austrian DPV multicentre survey. Arch Dis Child. 2014;99:738-43. Medline:24812301 doi:10.1136/archdischild-2013-304237

18 Onkamo P, Väänänen S, Karvonen M, Tuomilehto J. Worldwide increase in incidence of Type I diabetes - the analysis of the data on published incidence trends. Diabetologia. 1999;42:1395-403. Medline:10651256 doi:10.1007/s001250051309

19 Bell RA, Mayer-Davis EJ, Beyer JW, D’Agostino RB Jr, Lawrence JM, Linder B, et al. Diabetes in non-Hispanic white youth: prevalence, incidence, and clinical characteristics: the SEARCH for Diabetes in Youth Study. Diabetes Care. 2009;32 Suppl 2:S102-11. Medline:19246575 doi:10.2337/dc09-S202

20 Dabelea D, Mayer-Davis EJ, Saydah S, Imperatore G, Linder B, Divers J, et al. Prevalence of type 1 and type 2 diabetes among children and adolescents from 2001 to 2009. JAMA. 2014;311:1778-86. Medline:24794371 doi:10.1001/ jama.2014.3201

21 Bratina N, Shalitin S, Phillip M, Battelino. Type 1 diabetes in the young: Organization of two national centers in israel and slovenia. Zdr Varst. 2015;54:139-45. Medline:27646921

22 Harding JL, Shaw JE, Peeters A, Guiver T, Davidson S, Magliano DJ. Mortality trends among people with type 1 and type 2 diabetes in Australia: 1997-2010. Diabetes Care. 2014;37:2579-86. Medline:24947787 doi:10.2337/dc14-0096

23 Battelino T, Krzisnik C. Incidence of type 1 diabetes mellitus in children in Slovenia during the years 1988-1995. Acta Diabetol. 1998;35:112-4. Medline:9747966 doi:10.1007/s005920050115

24 World Health Organization. Diabetes Mellitus: report of a WHO study group. Technical Report Series no. 727. Geneva: World Health Organization; 1985.

25 Alberti KG, Zimmet PZ. Definition, diagnosis and classification of diabetes mellitus and its complications. Part 1: diagnosis and classification of diabetes mellitus provisional report of a WHO consultation. Diabet Med. 1998;15:539-53. Medline:9686693 doi:10.1002/(SICI)1096-9136(199807)15:7<539::AID-DIA668>3.0.CO;2-S

26 Gabir MM, Hanson RL, Dabelea D, Imperatore G, Roumain J, Bennett PH, et al. The 1997 American Diabetes Association and 1999 World Health Organization criteria for hyperglycemia in the diagnosis and prediction of diabetes. Diabetes Care. 2000;23:1108-12. Medline:10937506 doi:10.2337/diacare.23.8.1108 
27 Levitt NS, Unwin NC, Bradshaw D, Kitange HM, Mbanya JC, Mollentze WF, et al. Application of the new ADA criteria for the diagnosis of diabetes to population studies in sub-Saharan Africa. American Diabetes Association. Diabet Med. 2000;17:381-5. Medline:10872538 doi:10.1046/j.1464-5491.2000.00264.x

28 World Health Organization. Definition and diagnosis of diabetes mellitus and intermediate hyperglycemia: report of a WHO/IDF consultation. Geneva: World Health Organization; 2006.

29 Balshem H, Helfand M, Schunemann HJ, Oxman AD, Kunz R, Brozek J, et al. GRADE guidelines: 3. Rating the quality of evidence. J Clin Epidemiol. 2011;64:401-6. Medline:21208779 doi:10.1016/j.jclinepi.2010.07.015

30 DerSimonian R, Laird N. Meta-Analysis in Clinical Trials. Control Clin Trials. 1986;7:177-88. Medline:3802833 doi:10.1016/0197-2456(86)90046-2

31 Brinks R, Landwehr S. A new relation between prevalence and incidence of a chronic disease. Math Med Biol. 2015;32:42535. Medline:25576933

32 United Nations. World Population Prospects: The 2017 Revision. New York City, NY: United Nations; 2017.

33 Fakhfakh R, Haddouk S, Hadj Hamida YB, Kamoun T, Ayed MB, Hachicha M, et al. Pancreatic autoantibodies in Tunisian children with newly diagnosed type 1 diabetes. Pathol Biol (Paris). 2008;56:130-2. Medline:18178035 doi:10.1016/j. patbio.2007.09.019

34 Abduljabbar MA, Aljubeh JM, Amalraj A, Cherian MP. Incidence trends of childhood type 1 diabetes in eastern Saudi Arabia. Saudi Med J. 2010;31:413-8. Medline:20383419

35 Abdul-Rasoul M, Al-Qattan H, Al-Haj A, Habib H, Ismael A. Incidence and seasonal variation of Type 1 diabetes in children in Farwania area, Kuwait (1995-1999). Diabetes Res Clin Pract. 2002;56:153-7. Medline:11891024 doi:10.1016/ S0168-8227(01)00371-0

36 Ajlouni K, Qusous Y, Khawaldeh AK, Jaddou H, Batiehah A, Ammari F, et al. Incidence of insulin-dependent diabetes mellitus in Jordanian children aged 0-14 years during 1992-1996. Acta Paediatr Suppl. 1999;88:11-3. Medline:10195848 doi:10.1111/j.1651-2227.1999.tb14334.x

37 Altobelli E, Chiarelli F, Valenti M, Verrotti A, Tumini S, Di Orio F. Incidence of insulin-dependent diabetes mellitus (O14 years) in the Abruzzo Region, Italy, 1990-1995: results from a population-based register. J Pediatr Endocrinol Metab. 1998;11:555-62. Medline:9777577 doi:10.1515/JPEM.1998.11.4.555

38 Arpi ML, Fichera G, Mancuso M, Lucenti C, Italia S, Tomaselli L, et al. A ten-year (1989-1998) perspective study of the incidence of Type 1 diabetes in the district of Catania (Sicily) in a 0-14 year age group. J Endocrinol Invest. 2002;25:4149. Medline:12035936 doi:10.1007/BF03344030

39 Bahillo MP, Hermoso F, Ochoa C, Garcia-Fernandez JA, Rodrigo J, Marugan JM, et al. Incidence and prevalence of type 1 diabetes in children aged <15 yr in Castilla-Leon (Spain). Pediatr Diabetes. 2007;8:369-73. Medline:18036062 doi:10.1111/j.1399-5448.2007.00255.x

40 Barat P, Valade A, Brosselin P, Alberti C, Maurice-Tison S, Levy-Marchal C. The growing incidence of type 1 diabetes in children: the 17-year French experience in Aquitaine. Diabete Metab. 2008;34:601-5. Medline:18952477 doi:10.1016/j. diabet.2008.06.002

41 Bizzarri C, Patera PI, Arnaldi C, Petrucci S, Bitti ML, Scrocca R, et al. Incidence of type 1 diabetes has doubled in Rome and the Lazio region in the 0- to 14-year age-group: a 6-year prospective study (2004-2009). Diabetes Care. 2010;33:e140. Medline:20980419 doi:10.2337/dc10-1168

42 Blanchard JF, Dean H, Anderson K, Wajda A, Ludwig S, Depew N. Incidence and prevalence of diabetes in children aged 0-14 years in Manitoba, Canada, 1985-1993. Diabetes Care. 1997;20:512-5. Medline:9096971 doi:10.2337/diacare.20.4.512

43 Bratina NU, Tahirovic H, Battelino T, Krzisnik C. Incidence of childhood-onset Type I diabetes in Slovenia and the Tuzla region (Bosnia and Herzegovina) in the period 1990-1998. Diabetologia. 2001;44 Suppl 3:B27-31. Medline:11724412 doi:10.1007/PL00002949

44 Bruno G, Novelli G, Panero F, Perotto M, Monasterolo F, Bona G, et al. The incidence of type 1 diabetes is increasing in both children and young adults in Northern Italy: 1984-2004 temporal trends. Diabetologia. 2009;52:2531-5. Medline:19821110 doi:10.1007/s00125-009-1538-x

45 Campbell-Stokes PL, Taylor BJ; New Zealand Children's Diabetes Working Group. Prospective incidence study of diabetes mellitus in New Zealand children aged 0 to 14 years. Diabetologia. 2005;48:643-8. Medline:15759108 doi:10.1007/ s00125-005-1697-3

46 Carle F, Gesuita R, Bruno G, Coppa GV, Falorni A, Lorini R, et al. Diabetes incidence in 0- to 14-year age-group in Italy: a 10-year prospective study. Diabetes Care. 2004;27:2790-6. Medline:15562186 doi:10.2337/diacare.27.12.2790

47 Carrasco E, Angel B, Codner E, Garcia D, Ugarte F, Bruzzone ME, et al. Type 1 diabetes mellitus incidence in Santiago, Chile. Analysis by counties in the period 2000-2004. Rev Med Chil. 2006;134:1258-64. Medline:17186095 doi:10.4067/ S0034-98872006001000007

48 Casu A, Pascutto C, Bernardinelli L, Songini M. Type 1 diabetes among Sardinian children is increasing: the Sardinian diabetes register for children aged 0-14 years (1989-1999). Diabetes Care. 2004;27:1623-9. Medline:15220238 doi:10.2337/diacare.27.7.1623

49 Cepedano Dans A, Barreiro Conde J, Pombo Arias M. Grupo de Diabetes Infantil de G. Incidence and clinical manifestations at onset of type 1 diabetes mellitus in Galicia (Spain): 2001- 2002. Anal Pediatr (Barc). 2005;62:123-7. Medline:15701307 doi:10.1157/13071308

50 Cherubini V, Cantarini M, Ravaglia E, Bartolotta E. Incidence of IDDM in the Marche Region, Italy. Diabetes Care. 1994;17:432-5. Medline:8062612 doi:10.2337/diacare.17.5.432 
51 Cinek O, Lanska V, Kolouskova S, Sumnik Z, Snajderova M, Ronningen KS, et al. Type 1 diabetes mellitus in Czech children diagnosed in 1990-1997: a significant increase in incidence and male predominance in the age group 0-4 years. Collaborators of the Czech Childhood Diabetes Registry. Diabet Med. 2000;17:64-9. Medline:10691162 doi:10.1046/ j.1464-5491.2000.00202.x

52 Dahlquist GG, Nystrom L, Patterson CC. Swedish Childhood Diabetes Study G, Diabetes Incidence in Sweden Study G. Incidence of type 1 diabetes in Sweden among individuals aged 0-34 years, 1983-2007: an analysis of time trends. Diabetes Care. 2011;34:1754-9. Medline:21680725 doi:10.2337/dc11-0056

53 Demirbilek H, Ozbek MN, Baran RT. Incidence of type 1 diabetes mellitus in Turkish children from the southeastern region of the country: a regional report. J Clin Res Pediatr Endocrinol. 2013;5:98-103. Medline:23748062 doi:10.4274/ Jcrpe. 954

54 Carrillo Dominguez A. Incidence of type 1 diabetes mellitus in the Canary Islands (1995-1996). Epidemiologic Group of the Canary Society of Endocrinology and Nutrition. Rev Clin Esp. 2000;200:257-60. Medline:10901003 doi:10.1016/ S0014-2565(00)70625-4

55 Dziatkowiak H, Ciechanowska M, Wasikowa R, Symonides-lawecka A, Bieniasz J, Trippenbach-Dulska H, et al. Increase in the incidence of type 1 diabetes mellitus in children in three cities in Poland, 1987-1999. J Pediatr Endocrinol Metab. 2002;15:1153-60. Medline:12387513 doi:10.1515/JPEM.2002.15.8.1153

56 Feltbower RG, Bodansky HJ, McKinney PA, Houghton J, Stephenson CR, Haigh D. Trends in the incidence of childhood diabetes in south Asians and other children in Bradford, UK. Diabet Med. 2002;19:162-6. Medline:11874434 doi:10.1046/j.1464-5491.2002.00691.x

57 Ferreira SR, Franco LJ, Vivolo MA, Negrato CA, Simoes AC, Ventureli CR. Population-based incidence of IDDM in the state of Sao Paulo, Brazil. Diabetes Care. 1993;16:701-4. Medline:8495607 doi:10.2337/diacare.16.5.701

58 Formosa N, Calleja N, Torpiano J. Incidence and modes of presentation of childhood type 1 diabetes mellitus in Malta between 2006 and 2010. Pediatr Diabetes. 2012;13:484-8. Medline:22151907 doi:10.1111/j.1399-5448.2011.00839.x

59 Frongia O, Mastinu F, Sechi GM. Prevalence and 4-year incidence of insulin-dependent diabetes mellitus in the province of Oristano (Sardinia, Italy). Acta Diabetol. 1997;34:199-205. Medline:9401641 doi:10.1007/s005920050074

60 Goday A, Castell C, Tresserras R, Canela J, Taberner JL, Lloveras G. Incidence of type 1 (insulin-dependent) diabetes mellitus in Catalonia, Spain. The Catalan Epidemiology Diabetes Study Group. Diabetologia. 1992;35:267-71. Medline: 1563583 doi:10.1007/BF00400928

61 Galler A, Stange T, Muller G, Nake A, Vogel C, Kapellen T, et al. Incidence of childhood diabetes in children aged less than 15 years and its clinical and metabolic characteristics at the time of diagnosis: data from the Childhood Diabetes Registry of Saxony, Germany. Horm Res Paediatr. 2010;74:285-91. Medline:20516654 doi:10.1159/000303141

62 Gyurus EK, Patterson C, Soltesz G. Hungarian Childhood Diabetes Epidemiology Gropu. Twenty-one years of prospective incidence of childhood type 1 diabetes in Hungary - the rising trend continues (or peaks and highlands?). Pediatr Diabetes. 2012;13:21-5. Medline:22060160 doi:10.1111/j.1399-5448.2011.00826.x

63 Habeb AM, Al-Magamsi MS, Halabi S, Eid IM, Shalaby S, Bakoush O. High incidence of childhood type 1 diabetes in Al-Madinah, North West Saudi Arabia (2004-2009). Pediatr Diabetes. 2011;12:676-81. Medline:21418457 doi:10.1111/ j.1399-5448.2011.00765.x

64 Harjutsalo V, Sjoberg L, Tuomilehto J. Time trends in the incidence of type 1 diabetes in Finnish children: a cohort study. Lancet. 2008;371:1777-82. Medline:18502302 doi:10.1016/S0140-6736(08)60765-5

65 Harjutsalo V, Sund R, Knip M, Groop PH. Incidenceof type 1 diabetes in Finland. JAMA. 2013;310:427-8. Medline:23917294 doi:10.1001/jama.2013.8399

66 Jarosz-Chobot P, Deja G, Polanska J. Epidemiology of type 1 diabetes among Silesian children aged 0-14 years, 1989 2005. Acta Diabetol. 2010;47:29-33. Medline:19183839 doi:10.1007/s00592-009-0094-7

67 Chobot A, Polanska J, Brandt A, Deja G, Glowinska-Olszewska B, Pilecki O, et al. Updated 24-year trend of Type 1 diabetes incidence in children in Poland reveals a sinusoidal pattern and sustained increase. Diabet Med. 2017;34:1252-8. Medline:28257151 doi:10.1111/dme.13345

68 Joner G, Stene LC, Sovik O; Norwegian Childhood Diabetes Study Group. Nationwide, prospective registration of type 1 diabetes in children aged <15 years in Norway 1989-1998: No increase but significant regional variation in incidence. Diabetes Care. 2004;27:1618-22. Medline:15220237 doi:10.2337/diacare.27.7.1618

69 Kadiki OA, Roaeid RB. Incidence of type 1 diabetes in children (0-14 years) in Benghazi Libya (1991-2000). Diabetes Metab. 2002;28:463-7. Medline:12522326

70 Koton S, Israel IRSGI. Incidence of type 1 diabetes mellitus in the 0- to 17-yr-old Israel population, 1997-2003. Pediatr Diabetes. 2007;8:60-6. Medline:17448128 doi:10.1111/j.1399-5448.2007.00230.x

71 Lee WW, Ooi BC, Thai AC, Loke KY, Tan YT, Rajan U, et al. The incidence of IDDM in Singapore children. Singapore Med J. 1998;39:359-62. Medline:9844497

72 Levy-Marchal C, Papoz L, de Beaufort C, Doutreix J, Froment V, Voirin J, et al. Incidence of insulin-dependent diabetes occurring before 20 years of age in France. Pediatrie. 1991;46:367-71. Medline:1652744

73 Lipman TH, Levitt Katz LE, Ratcliffe SJ, Murphy KM, Aguilar A, Rezvani I, et al. Increasing incidence of type 1 diabetes in youth: twenty years of the Philadelphia Pediatric Diabetes Registry. Diabetes Care. 2013;36:1597-603. Medline:23340888 doi:10.2337/dc12-0767

74 Mazzella M, Cotellessa M, Bonassi S, Mulas R, Caratozzolo A, Gaber S, et al. Incidence of type I diabetes in the Liguria Region, Italy. Results of a prospective study in a O- to 14-year age-group. Diabetes Care. 1994;17:1193-6. Medline:7821142 doi:10.2337/diacare.17.10.1193 
75 Michalkova DM, Cernay J, Dankova A, Rusnak M, Fandakova K. Incidence and prevalence of childhood diabetes in Slovakia (1985-1992). Slovak Childhood Diabetes Epidemiology Study Group. Diabetes Care. 1995;18:315-20. Medline: 7555473 doi:10.2337/diacare.18.3.315

76 Michalkova D, Minarik P, Hlava P, Camajova J, Nazarov V, Slovak D. Epidemiological Study Group of Children. Trends in the incidence of childhood-onset type 1 diabetes in Slovakia 1985-2000. Cent Eur J Publ Hlth. 2004;12:75-7.

77 Neu A, Kehrer M, Hub R, Ranke MB. Incidence of IDDM in German children aged 0-14 years. A 6-year population-based study (1987-1993). Diabetes Care. 1997;20:530-3. Medline:9096975 doi:10.2337/diacare.20.4.530

78 Panamonta O, Thamjaroen J, Panamonta M, Panamonta N, Suesirisawat C. The rising incidence of type 1 diabetes in the northeastern part of Thailand. J Med Assoc Thai. 2011;94:1447-50. Medline:22295730

79 Pinelli L, Mormile R, Gonfiantini E, Busato A, Kaufmann P, Piccoli R, et al. Recommended dietary allowances (RDA) in the dietary management of children and adolescents with IDDM: an unfeasible target or an achievable cornerstone? J Pediatr Endocrinol Metab. 1998;11 Suppl 2:335-46. Medline:9642664

80 Pishdad GR. Low incidence of type 1 diabetes in Iran. Diabetes Care. 2005;28:927-8. Medline:15793198 doi:10.2337/ diacare.28.4.927

81 Pundziute-Lyckl A, Dahlquist G, Nystrom L, Arnqvist H, Bjork E, Blohme G, et al. The incidence of Type I diabetes has not increased but shifted to a younger age at diagnosis in the 0-34 years group in Sweden 1983-1998. Diabetologia. 2002;45:783-91. Medline:12107721 doi:10.1007/s00125-002-0845-2

82 Radosevic B, Bukara-Radujkovic G, Miljkovic V, Pejicic S, Bratina N, Battelino T. The incidence of type 1 diabetes in Republic of Srpska (Bosnia and Herzegovina) and Slovenia in the period 1998- 2010. Pediatr Diabetes. 2013;14:273-9. Medline:22925312 doi:10.1111/j.1399-5448.2012.00898.x

83 Aude Rueda O, Libman IM, Altamirano Bustamante N, Robles Valdes C, LaPorte RE. Low incidence of IDDM in children of Veracruz-Boca del Rio, Veracruz. Results of the first validated IDDM registry in Mexico. Diabetes Care. 1998;21:13723. Medline: 9702456 doi:10.2337/diacare.21.8.1372

84 Roche EF, McKenna A, Ryder K, Brennan A, O’Regan M, Hoey H. The incidence of childhood type 1 diabetes in Ireland and the National Childhood Diabetes Register. Ir Med J. 2014;107:278-81. Medline:25417386

85 Roche EF, Menon A, Gill D, Hoey H. Clinical presentation of type 1 diabetes. Pediatr Diabetes. 2005;6:75-8. Medline:15963033 doi:10.1111/j.1399-543X.2005.00110.x

86 Serban V, Timar R, Dabelea D, Green A, McKinney P, Law G, et al. The epidemiology of childhood-onset type 1 diabetes mellitus in Romania. ONROCAD Study Group. National Romanian Organisation for the Care of Diabetic Children and Adolescents. J Pediatr Endocrinol Metab. 2001;14:535-41. Medline:11393575 doi:10.1515/JPEM.2001.14.5.535

87 Schranz AG. Trends in incidence of childhood type 1 diabetes in Malta. Diabetes Care. 1998;21:194-5. Medline:9538996 doi:10.2337/diacare.21.1.194

88 Skordis N, Efstathiou E, Kyriakides TC, Savvidou A, Savva SC, Phylactou LA, et al. Epidemiology of type 1 diabetes mellitus in Cyprus: rising incidence at the dawn of the 21st century. Hormones. 2012;11:86-93. Medline:22450348 doi:10.1007/BF03401541

89 Skrivarhaug T, Stene LC, Drivvoll AK, Strřm H, Joner G; Norwegian Childhood Diabetes Study Group. Incidence of type 1 diabetes in Norway among children aged 0-14 years between 1989 and 2012: has the incidence stopped rising? Results from the Norwegian Childhood Diabetes Registry. Diabetologia. 2014;57:57-62. Medline:24149838 doi:10.1007/ s00125-013-3090-y

90 Smith TL, Drum ML, Lipton RB. Incidence of childhood type I and non-type 1 diabetes mellitus in a diverse population: the Chicago Childhood Diabetes Registry, 1994 to 2003. J Pediatr Endocrinol Metab. 2007;20:1093-107. Medline:18051928 doi:10.1515/JPEM.2007.20.10.1093

91 Songini M, Bernardinelli L, Clayton D, Montomoli C, Pascutto C, Ghislandi M, et al. The Sardinian IDDM study: 1. Epidemiology and geographical distribution of IDDM in Sardinia during 1989 to 1994. Diabetologia. 1998;41:221-7. Medline:9498657 doi:10.1007/s001250050893

92 Soliman AT, al-Salmi IS, Asfour MG. Epidemiology of childhood insulin-dependent diabetes mellitus in the Sultanate of Oman. Diabet Med. 1996;13:582-6. Medline:8799664 doi:10.1002/(SICI)1096-9136(199606)13:6<582::AIDDIA1 14>3.0.CO;2-E

93 Staines A, Hanif S, Ahmed S, McKinney PA, Shera S, Bodansky HJ. Incidence of insulin dependent diabetes mellitus in Karachi, Pakistan. Arch Dis Child. 1997;76:121-3. Medline:9068300 doi:10.1136/adc.76.2.121

94 Stipancic G, La Grasta Sabolic L, Malenica M, Radica A, Skrabic V, Tiljak MK. Incidence and trends of childhood Type 1 diabetes in Croatia from 1995 to 2003. Diabetes Res Clin Pract. 2008;80:122-7. Medline:18055059 doi:10.1016/j diabres.2007.10.019

95 Teeaar T, Liivak N, Heilman K, Kool P, Sor R, Paal M, et al. Increasing incidence of childhood- onset type 1 diabetes mellitus among Estonian children in 1999-2006. Time trend analysis 1983- 2006. Pediatr Diabetes. 2010;11:107-10. Medline:19496966 doi:10.1111/j.1399-5448.2009.00535.x

96 Tenconi MT, Devoti G, Albani I, Lorini R, Martinetti M, Fratino P, et al. IDDM in the province of Pavia, Italy, from a population-based registry. A descriptive study. Diabetes Care. 1995;18:1017-9. Medline:7555534 doi:10.2337/diacare.18.7.1017

97 Zorrilla Torras B, Cantero Real JL, Barrios Castellanos R, Ramirez Fernandez J, Argente Oliver J, Gonzalez Vergaz A, et al. Incidence of type 1 diabetes mellitus in children: results from the population registry of the Madrid Region, 1997-2005. Med Clin (Barc). 2009;132:545-8. Medline:19285324 doi:10.1016/j.medcli.2008.05.020 
98 Tuomilehto J, Dabee J, Karvonen M, Dowse GK, Gareeboo H, Virtala E, et al. Incidence of IDDM in Mauritian children and adolescents from 1986 to 1990. Diabetes Care. 1993;16:1588-91. Medline:8299454 doi:10.2337/diacare.16.12.1588

99 Tuomilehto J, Virtala E, Karvonen M, Lounamaa R, Pitkaniemi J, Reunanen A, et al. Increase in incidence of insulin-dependent diabetes mellitus among children in Finland. Int J Epidemiol. 1995;24:984-92. Medline:8557457 doi:10.1093/ ije/24.5.984

100 Tuomilehto J, Karvonen M, Padaiga Z, Tuomilehto-Wolf E, Kohtamaki K. Epidemiology of insulin-dependent diabetes mellitus around the Baltic Sea. The DIABALT Study Group. Horm Metab Res. 1996;28:340-3. Medline:8858381 doi:10.1055/s-2007-979810

101 Vehik K, Hamman RF, Lezotte D, Norris JM, Klingensmith G, Bloch C, et al. Increasing incidence of type 1 diabetes in 0- to 17-year-old Colorado youth. Diabetes Care. 2007;30:503-9. Medline:17327312 doi:10.2337/dc06-1837

102 Verge CF, Silink M, Howard NJ. The incidence of childhood IDDM in New South Wales, Australia. Diabetes Care. 1994;17:693-6. Medline:7924779 doi:10.2337/diacare.17.7.693

103 Wadsworth E, Shield J, Hunt L, Baum D. Insulin dependent diabetes in children under 5: incidence and ascertainment validation for 1992. BMJ. 1995;310:700-3. Medline:7711537 doi:10.1136/bmj.310.6981.700

104 Wong GW, Leung SS, Oppenheimer SJ. Epidemiology of IDDM in southern Chinese children in Hong Kong. Diabetes Care. 1993;16:926-8. Medline:8325208 doi:10.2337/diacare.16.6.926

105 Wu D, Kendall D, Lunt H, Willis J, Darlow B, Frampton C. Prevalence of Type 1 diabetes in New Zealanders aged 0-24 years. N Z Med J. 2005;118:U1557. Medline:16027748

106 Zung A, Blumenfeld O, Shehadeh N, Dally Gottfried O, Tenenbaum Rakover Y, Hershkovitz E, et al. Increase in the incidence of type 1 diabetes in Israeli children following the Second Lebanon War. Pediatr Diabetes. 2012;13:326-33. Medline:22151880 doi:10.1111/j.1399-5448.2011.00838.x

107 Diaz N, Mendez MA, Perez-Bravo F, Carrasco E, Santos JL. Incidence rate of type 1 diabetes in Santiago (Chile) by HLADQA1 and DQB1 genotypes. Eur J Epidemiol. 2003;18:787-92. Medline:12974555 doi:10.1023/A:1025345804789

108 Karvonen M, Pitkaniemi J, Tuomilehto J. The onset age of type 1 diabetes in Finnish children has become younger. The Finnish Childhood Diabetes Registry Group. Diabetes Care. 1999;22:1066-70. Medline:10388969 doi:10.2337/ diacare.22.7.1066

109 International Diabetes Federation. IDF Diabetes Atlas, 8th edn. Brussels, Belgium: International Diabetes Federation; 2017.

110 Green A, Gale EA, Patterson CC. Incidence of childhood-onset insulin-dependent diabetes mellitus: the EURODIAB ACE Study. Lancet. 1992;339:905-9. Medline:1348306 doi:10.1016/0140-6736(92)90938-Y

111 Yang Z, Long X, Shen J, Liu D, Dorman JS, Laporte RE, et al. Epidemics of type 1 diabetes in China. Pediatr Diabetes. 2005;6:122-8. Medline:16109067 doi:10.1111/j.1399-543X.2005.00116.x

112 Karvonen M, Tuomilehto J, Virtala E, Pitkaniemi J, Reunanen A, Tuomilehto-Wolf E, et al. Seasonality in the clinical onset of insulin-dependent diabetes mellitus in Finnish children. Childhood Diabetes in Finland (DiMe) Study Group. Am J Epidemiol. 1996;143:167-76. Medline:8546118 doi:10.1093/oxfordjournals.aje.a008726

113 Galler A, Lindau M, Ernert A, Thalemann R, Raile K. Associations between media consumption habits, physical activity, socioeconomic status, and glycemic control in children, adolescents, and young adults with type 1 diabetes. Diabetes Care. 2011;34:2356-9. Medline:21926289 doi:10.2337/dc11-0838

114 Muntoni S, Muntoni S. New insights into the epidemiology of type 1 diabetes in Mediterranean countries. Diabetes Metab Res Rev. 1999;15:133-40. Medline:10362460 doi:10.1002/(SICI)1520-7560(199903/04)15:2<133::AID-DMRR2O>3.0.CO;2-V 